\title{
A role for the alpha-8 integrin chain (itga8) in glomerular homeostasis of the kidney
}

\author{
Ines Marek ${ }^{1^{*}} \mathbb{D}$, Karl Friedrich Hilgers ${ }^{2}$, Wolfgang Rascher ${ }^{1}$, Joachim Woelfle ${ }^{1}$ and Andrea Hartner ${ }^{1}$
}

\begin{abstract}
Glomerulonephritis results in a dysregulation of glomerular cells and may end up in chronic alterations and subsequent loss of renal function. Therefore, understanding mechanisms, which contribute to maintain glomerular integrity, is a pivotal prerequisite for therapeutic interventions. The alpha-8 integrin chain seems to be an important player to maintain glomerular homeostasis by conferring mechanical stability and functional support for the renal capillary tuft.
\end{abstract}

Keywords: itga8, Glomerular homeostasis, Mesangial cells, Glomerulonephritis

\section{Introduction}

Several forms of glomerulonephritis (e.g. IgA nephritis) are among the most common acquired renal diseases in childhood [1]. Although glomerulonephritis in many cases heals spontaneously, there is still a part of cases ending up in chronic renal disease with reduced kidney function. The mechanisms contributing to healing of the glomerular damage and preventing progressive loss of renal function are yet incompletely understood. Dysregulation of glomerular mesangial cells is frequently seen in various forms of glomerulonephritis [2], especially in mesangioproliferative IgA nephritis. Mesangial cells are one major cell type of the glomerulus, together with podocytes and endothelial cells of the capillary tuft. In other diseases, such as diabetic nephropathy or membranous glomerulopathy for instance, epithelial cells, especially podocytes, are primarily damaged. Endothelial cell diseases in turn are due to subendothelial immune complex deposition or the attachment of antiglomerular basement membrane antibodies (Goodpasture syndrome) or due to an activation of coagulation (HUS) [3].

Mesangial cells not only offer a structural support for the capillary tuft, but also regulate capillary tone owing

\footnotetext{
* Correspondence: ines.marek@uk-erlangen.de

${ }^{1}$ Department of Pediatrics and Adolescent Medicine, University Hospital of

Erlangen, Loschgestrasse 15, 91054 Erlangen, Germany

Full list of author information is available at the end of the article
}

to their contractile properties. Furthermore, they serve as non-professional phagocytes to clear the capillary filtration apparatus from cellular debris [4]. Upon activation, mesangial cells are able to synthetize numerous cytokines and matrix molecules contributing to glomerulosclerotic changes [5]. Thus, mesangial cells are important players in preserving glomerular homeostasis.

\section{Integrins}

Integrins are heterodimeric glycoproteins, consisting of an alpha and a beta subunit. The majority of these integrins functions as a receptor to extracellular matrix proteins via non-covalent binding. Depending on the combination of alpha and beta subunits, they form receptors for different ligands. Integrin receptors are pleiotropic, that is, one integrin can bind several ligands and one ligand can be recognized by several integrins $[6,7]$. Ligand binding results in conformational changes of integrins to confer intracellular signalling cascades to influence cell shape by rearrangement of the cytoskeleton and to affect cell behaviour, such as cell differentiation, survival, proliferation and migration [8-10].

\section{The alpha-8 integrin (itga8) chain}

itga 8 is an integrin chain which is predominantly expressed on mesenchymal cells (vascular smooth muscle cells, some fibroblasts, mesangial cells). It forms a heterodimer with itgb1 to serve as a receptor for RGD- 
containing matrix molecules (fibronectin, vitronectin, tenascin $\mathrm{C}$, osteopontin and nephronectin), similar to itgav and itga5 integrins [11]. itga8 is known to have important functions for kidney development. The critical developmental step of the kidney is the reciprocal interaction of the epithel of the ureteric bud (arising from the Wolffian duct) and its surrounding metanephric mesenchyme, which is necessary to induce ureteric bud outgrowth and differentiation of nephrons from the metanephric mesenchyme. Defects in these processes can result in congenital abnormalities of the kidney and urinary tract (CAKUT) [12]. Mice deficient for itga8 display reduced renal mass or even renal agenesis [13]. itga8 is normally expressed on cells of the condensing mesenchyme and ligates nephronectin (an extracellular matrix protein with an RGD motif, [14]), which in turn is expressed by epithelial cells of the ureteric bud. Under normal circumstances this interaction induces a signalling cascade to enhance expression of GDNF in the metanephric mesenchyme. In case of a deficiency of itga8, this epithelial-mesenchymal interaction is disturbed, and as a consequence, sprouting of the ureteric bud is impaired [15]. The resulting underexpression of GDNF finally results in a low nephron endowment [16]. Recent human genetic studies confirm a role of itga8 for kidney development, as mutations in the itga8 gene can result in renal agenesis in humans as well [17]. Expression of itga8 in the kidney is not confined to renal development, but can be detected in the differentiated kidney as well [18].

\section{itga8 in the glomerulus}

In the glomerulus, itga8 is specific for mesangial cells [18] (Fig. 1). This was recently confirmed by Lu et al. using single cell sequencing of mesangial cells [19]. There has been growing evidence for important regulatory properties of itga8 for the regulation of mesangial cell behaviour (see Fig. 2). In vitro studies using isolated wild type and itga8-deficient mesangial cells revealed that itga8 contributes to mesangial cell adhesion and spreading, while suppressing migration [20]. Therefore, itga8 might support firm adhesion of mesangial cells in vivo, conferring mechanical stability of the glomerulus. In accordance with this notion, it has been shown that itga8 increases mechanical stability of the glomerular capillary tuft in the DOCA-salt model of glomerular hypertension [21]. IgA nephropathy is a special form of glomerulonephritis characterized by hypercellularity as a consequence of mesangial proliferation [22]. Apoptosis of surplus cells and phagocytosis of extracellular matrix components and apoptotic cells are part of the clearing mechanisms and healing in glomerulonephritis [23, 24]. Suggestive of a role of itga8 for healing of glomerulonephritis, proliferation was increased in mesangial cells, which were deficient for itga8 [20], a feature that seems to be cell type specific, because a knock down of itga 8 reduced proliferation in epithelial cells [25]. itga8 not only seems to attenuate proliferation in mesangial cells, but also appears to protect cells from apoptosis, resulting in a low cell turnover rate [26, 27]. In mice deficient for itga8, healing of glomerulonephritis is delayed as apoptosis remains increased for a longer time than in wild type mice [27]. Some integrins are suspected to promote the expression of matrix molecules and subsequent fibrosis [28]. This is not true for itga8, which did not act profibrotic, neither in vitro [29], nor in vivo [30]. In vitro studies suggested that itga8 supports the mesenchymal phenotype of cells, because lack of itga8 results in loss of actin stress fibres and reorganization of the cytoskeleton [31]. This may result in a reduced contractility of the cell. These findings are supported by data obtained from vascular smooth muscle cells, where itga8 expression promotes the contractile phenotype [32]. Finally, itga8 expression seems to increase the phagocytotic capacity of cells [33]. The most effective phagocytosis of apoptotic cells (leukocytes or mesangial cells) as well as of matrix components was detected in the presence of itga8 on mesangial cells.

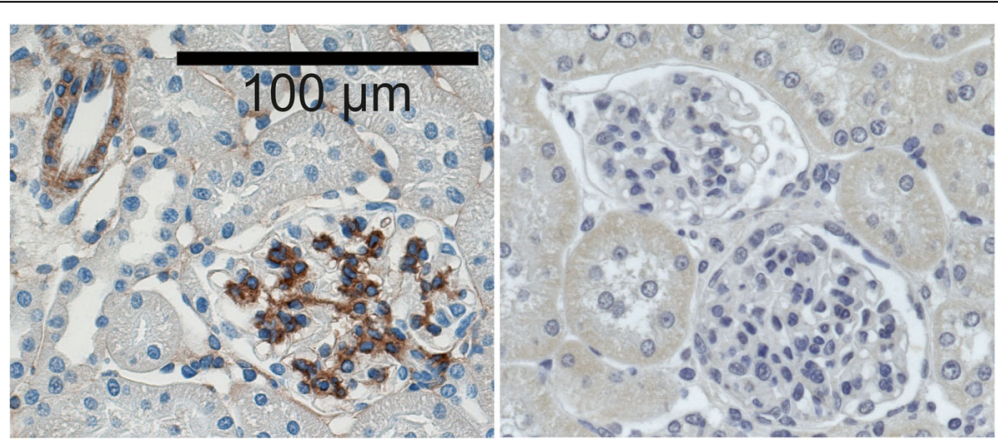

Fig. 1 Left: Immunohistochemical detection of itga8 in rat renal tissue (brown staining). Strong reactivity is detected in the mesangium of the glomerulus and some reactivity is detected in vascular smooth muscle cells. Right: Negative control using diluted preimmune serum instead of primary antibody 


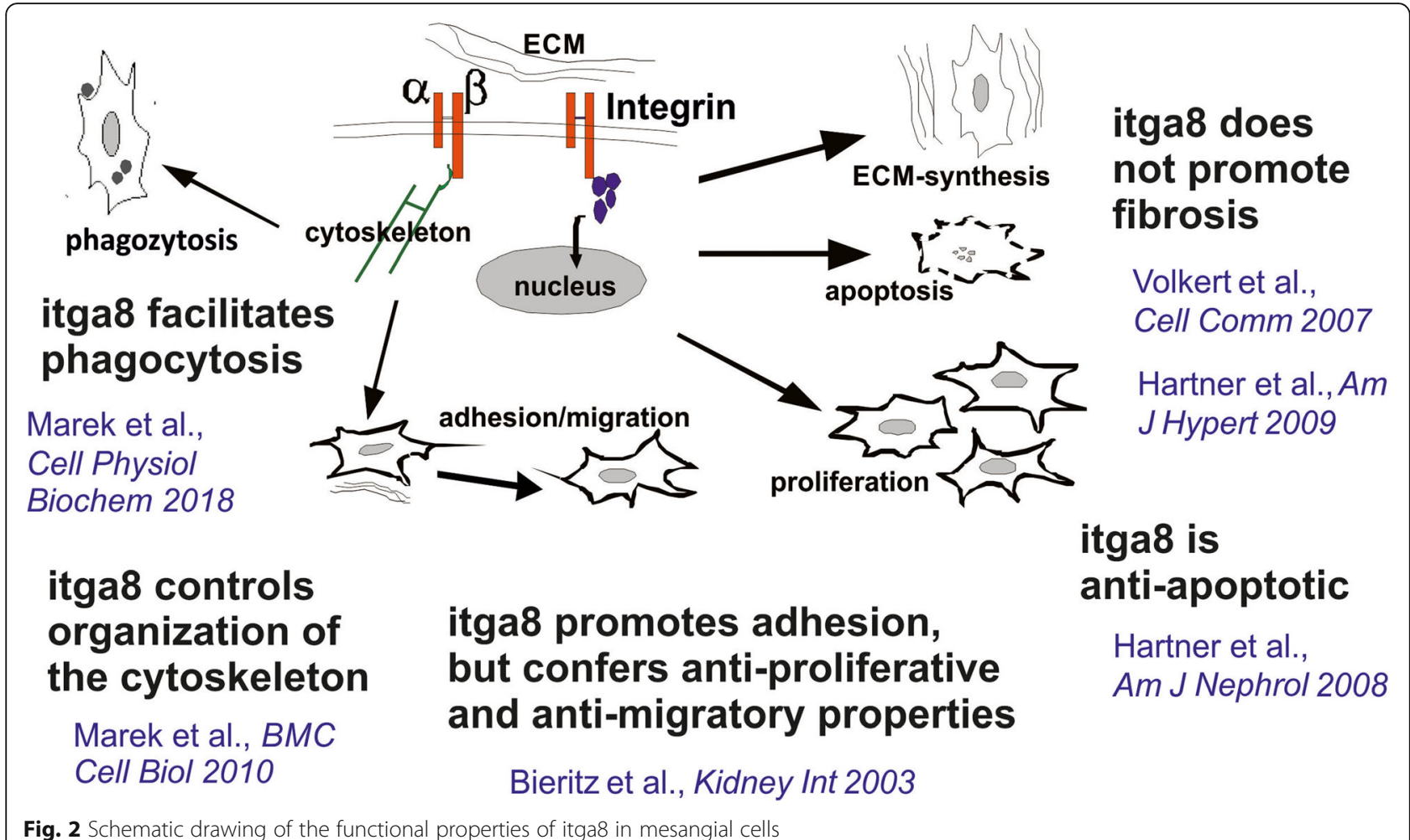

\section{Conclusion}

Taken together, there is strong evidence that itga8 supports essential functional properties of mesangial cells, like conferring mechanical stability, contractility and the ability to get rid of apoptotic cells and matrix debris from the glomerular filtration apparatus. itga8 is an important player in the proper function of the capillary tuft. itga8 signalling might aid in the resolution of glomerulonephritis and reduce the risk of chronification of glomerular disease. In view of the protective properties of itga8, targeting itga8, e.g. in an attempt to ameliorate fibrosis, does not seem reasonable to reduce renal injury. In contrast, expression of itga8 might serve as a risk stratification marker for the outcome of glomerular disease.

\section{Abbreviations}

DOCA: Desoxycorticosterone acetate; GDNF: Glial-derived neurotrophic

factor; itg: Integrin chain

\section{Acknowledgements}

We thank Rainer Wachtveitl, Miroslava Kupraszewicz-Hutzler, Gudrun Volkert, Robert Becker and Angelika Jahn for technical support and critical discussions

\section{Authors' contributions}

$\mathrm{IM}$ and $\mathrm{AH}$ performed the literature search and wrote the manuscript. $\mathrm{KFH}$, WR and JW critically revised the manuscript. The authors read and approved the final manuscript.

\section{Funding}

IM was recipient of an ELAN young investigator grant from the Friedrich-

Alexander University of Erlangen-Nürnberg and of an educational grant from the Interdisciplinary Center for Clinical Research of the Faculty of Medicine of the Friedrich-Alexander University Erlangen-Nürnberg. AH received funding from the Deutsche Forschungsgemeinschaft (SFB 423, A2). Open Access funding enabled and organized by Projekt DEAL.

Availability of data and materials Not applicable

Ethics approval and consent to participate Not applicable

Consent for publication

Not applicable

Competing interests

The authors declare that they have no competing interests.

\section{Author details}

1Department of Pediatrics and Adolescent Medicine, University Hospital of Erlangen, Loschgestrasse 15, 91054 Erlangen, Germany. ${ }^{2}$ Department of Nephrology and Hypertension, University Hospital of Erlangen, Ulmenweg 18, 91054 Erlangen, Germany.

Received: 9 April 2020 Accepted: 8 September 2020

Published online: 01 October 2020

References

1. Pan CG (1997) Glomerulonephritis in childhood. Curr Opin Pediatr 9:154159. https://doi.org/10.1097/00008480-199704000-00007

2. Veis JH, Yamashita W, Liu YJ, Ooi BS (1990) The biology of mesangial cells in glomerulonephritis. Proc Soc Exp Biol Med 195:160-167. https://doi.org/10. 3181/00379727-195-43129a

3. Kimmel M, Kuhlmann U (2015) Glomerulonephritis. In: Kuhlmann U, Böhler J, Luft FC, Alscher MD, Kunzendorf U (eds) Nephrologie, 6th edn. Georg Thieme Verlag, Stuttgart

4. Savill J, Smith J, Sarraf C, Ren Y, Abbott F, Rees A (1992) Glomerular mesangial cells and inflammatory macrophages ingest neutrophils 
undergoing apoptosis. Kidney Int 42:924-936. https://doi.org/10.1038/ki. 1992.369

5. Sterzel RB, Schulze-Lohoff E, Weber M, Goodman SL (1992) Interactions between glomerular mesangial cells, cytokines, and extracellular matrix. J Am Soc Nephrol 2:S126-S131

6. Hynes RO (2002) Integrins: bidirectional, allosteric signaling machines. Cell 110:673-687. https://doi.org/10.1016/s0092-8674(02)00971-6

7. Hynes RO (2004) The emergence of integrins: a personal and historical perspective. Matrix Biol 23:333-340. https://doi.org/10.1016/j.matbio.2004. 08.001

8. Streuli CH (2016) Integrins as architects of cell behavior. Mol Biol Cell 27: 2885-2888. https://doi.org/10.1091/mbc.E15-06-0369

9. Sayedyahossein S, Dagnino L (2013) Integrins and small GTPases as modulators of phagocytosis. Int Rev Cell Mol Biol 302:321-354. https://doi. org/10.1016/B978-0-12-407699-0.00006-6

10. Humphries MJ (2002) Insights into integrin-ligand binding and activation from the first crystal structure. Arthritis Res 4(Suppl 3):S69-S78. https://doi. org/10.1186/ar563

11. Hartner A, Dötsch J (2002) Lessons in congenital and acquired renal disease from alpha8 integrin mutant mice. Pediatr Nephrol 17:882-888. https://doi. org/10.1007/s00467-002-0950-y

12. Schedl A (2007) Renal abnormalities and their developmental origin. Nat Rev Genet 8:791-802. https://doi.org/10.1038/nrg2205

13. Müller U, Wang D, Denda S, Meneses JJ, Pedersen RA, Reichardt LF (1997) Integrin alpha8beta1 is critically important for epithelial-mesenchyma interactions during kidney morphogenesis. Cell 88:603-613. https://doi.org/ 10.1016/s0092-8674(00)81903-0

14. Brandenberger R, Schmidt A, Linton J, Wang D, Backus C, Denda S, Müller U, Reichardt LF (2001) Identification and characterization of a novel extracellular matrix protein nephronectin that is associated with integrin alpha8beta1 in the embryonic kidney. J Cell Biol 154:447-458. https://doi. org/10.1083/jcb.200103069

15. Linton JM, Martin GR, Reichardt LF (2007) The ECM protein nephronectin promotes kidney development via integrin alpha8beta1-mediated stimulation of Gdnf expression. Development 134:2501-2509. https://doi. org/10.1242/dev.005033

16. Cullen-McEwen LA, Drago J, Bertram JF (2001) Nephron endowment in glial cell line-derived neurotrophic factor (GDNF) heterozygous mice. Kidney Int 60:31-36. https://doi.org/10.1046/j.1523-1755.2001.00767.x

17. Humbert C, Silbermann F, Morar B, Parisot M, Zarhrate M, Masson C, Tores F, Blanchet P, Perez MJ, Petrov Y, Khau Van Kien P, Roume J, Leroy B, Gribouval O, Kalaydjieva L, Heidet L, Salomon R, Antignac C, Benmerah A, Saunier S, Jeanpierre C (2014) Integrin alpha 8 recessive mutations are responsible for bilateral renal agenesis in humans. Am J Hum Genet 94:288294. https://doi.org/10.1016/j.ajhg.2013.12.017

18. Hartner A, Schöcklmann H, Pröls F, Müller U, Sterzel RB (1999) Alpha8 integrin in glomerular mesangial cells and in experimental glomerulonephritis. Kidney Int 56:1468-1480. https://doi.org/10.1046/.15231755.1999.00662.x

19. Lu Y, Ye Y, Yang Q, Shi S (2017) Single-cell RNA-sequence analysis of mouse glomerular mesangial cells uncovers mesangial cell essential genes. Kidney Int 92:504-513. https://doi.org/10.1016/j.kint.2017.01.016

20. Bieritz B, Spessotto P, Colombatti A, Jahn A, Prols F, Hartner A (2003) Role of alpha8 integrin in mesangial cell adhesion, migration, and proliferation. Kidney Int 64:119-127. https://doi.org/10.1046/.1523-1755.2003.00057.x

21. Hartner A, Cordasic N, Klanke B, Müller U, Sterzel RB, Hilgers KF (2002) The alpha8 integrin chain affords mechanical stability to the glomerular capillary tuft in hypertensive glomerular disease. Am J Pathol 160:861-867. https:// doi.org/10.1016/s0002-9440(10)64909-7

22. Scindia YM, Deshmukh US, Bagavant H (2010) Mesangial pathology in glomerular disease: targets for therapeutic intervention. Adv Drug Deliv Rev 62:1337-1343. https://doi.org/10.1016/j.addr.2010.08.011

23. Baker AJ, Mooney A, Hughes J, Lombardi D, Johnson RJ, Savill J (1994) Mesangial cell apoptosis: the major mechanism for resolution of glomerular hypercellularity in experimental mesangial proliferative nephritis. J Clin Invest 94:2105-2116. https://doi.org/10.1172/jci117565

24. Watson S, Cailhier JF, Hughes J, Savill J (2006) Apoptosis and glomerulonephritis. Curr Dir Autoimmun 9:188-204. https://doi.org/10.1159/ 000090782

25. Benoit YD, Lussier C, Ducharme PA, Sivret S, Schnapp LM, Basora N, Beaulieu JF (2009) Integrin alpha8beta1 regulates adhesion, migration and proliferation of human intestinal crypt cells via a predominant RhoA/ROCKdependent mechanism. Biol Cell 101:695-708. https://doi.org/10.1042/ bc20090060

26. Farias E, Lu M, Li X, Schnapp LM (2005) Integrin alpha8beta1-fibronectin interactions promote cell survival via PI3 kinase pathway. Biochem Biophys Res Commun 329:305-311. https://doi.org/10.1016/j.bbrc.2005.01.125

27. Hartner A, Marek I, Cordasic N, Haas C, Schocklmann H, Hulsmann-Volkert G, Plasa I, Rascher W, Hilgers KF, Amann K (2008) Glomerular regeneration is delayed in nephritic alpha 8-integrin-deficient mice: contribution of alpha 8integrin to the regulation of mesangial cell apoptosis. Am J Nephrol 28: 168-178. https://doi.org/10.1159/000110022

28. Norman JT, Fine LG (1999) Progressive renal disease: fibroblasts, extracellular matrix, and integrins. Exp Nephrol 7:167-177. https://doi.org/10.1159/ 000020597

29. Volkert G, Jahn A, Dinkel C, Fahlbusch F, Zürn C, Hilgers KF, Rascher W, Hartner A, Marek I (2014) Contribution of the a8 integrin chain to the expression of extracellular matrix components. Cell Commun Adhes 21:8998. https://doi.org/10.3109/15419061.2013.876012

30. Hartner A, Cordasic N, Rascher W, Hilgers KF (2009) Deletion of the alpha8 integrin gene does not protect mice from myocardial fibrosis in DOCA hypertension. Am J Hypertens 22:92-99. https://doi.org/10.1038/ajh.2008.309

31. Marek I, Volkert G, Jahn A, Fahlbusch F, Zürn C, Ozcan Z, Goppelt-Struebe M, Hilgers KF, Rascher W, Hartner A (2010) Lack of a8 integrin leads to morphological changes in renal mesangial cells, but not in vascular smooth muscle cells. BMC Cell Biol 11:102. https://doi.org/10.1186/1471-2121-11-102

32. Zargham R, Touyz RM, Thibault G (2007) alpha 8 Integrin overexpression in de-differentiated vascular smooth muscle cells attenuates migratory activity and restores the characteristics of the differentiated phenotype. Atherosclerosis 195:303-312. https://doi.org/10 1016/j.atherosclerosis.2007.01.005

33. Marek I, Becker R, Fahlbusch FB, Menendez-Castro C, Rascher W, Daniel C, Volkert G, Hartner A (2018) Expression of the alpha8 integrin chain facilitates phagocytosis by renal mesangial cells. Cell Physiol Biochem 45:2161-2173. https://doi.org/10.1159/000488160

\section{Publisher's Note}

Springer Nature remains neutral with regard to jurisdictional claims in published maps and institutional affiliations.

\section{Submit your manuscript to a SpringerOpen ${ }^{\circ}$ journal and benefit from:}

- Convenient online submission

- Rigorous peer review

- Open access: articles freely available online

High visibility within the field

- Retaining the copyright to your article

Submit your next manuscript at $\boldsymbol{\nabla}$ springeropen.com 